\title{
Effects of Plant Density and the Application of Silica on Seed Yield and Yield Components of Rice (Oryza sativa L.)
}

\author{
Esmaeil Yasari ${ }^{1}$, Hossein Yazdpoor ${ }^{1}$, Hamid Poor Kolhar $^{2} \&$ Hamid Reza Mobasser $^{3}$ \\ ${ }^{1}$ Department of Agriculture, Payame Noor University, Iran \\ 2 Islamic Azad University, Chalus Branch, Iran \\ ${ }^{3}$ Faculty of Agricultural and Natural Resources, Department of Agronomy and Plant Breeding, Islamic Azad \\ University, Qaemshahr Branch, Iran
}

Correspondence: Esmaeil Yasari, Assisstant Prof. Department of Agriculture, Payame Noor University, Iran. E-mail: e_yassari@yahoo.com

Received: June 9, 2011 Accepted: June 22, 2011 Online Published: August 22, 2012

doi:10.5539/ijb.v4n4p46 URL: http://dx.doi.org/10.5539/ijb.v4n4p46

\begin{abstract}
In order to investigate the effects of plant density and the role silicon plays in determining the agronomic features of rice transplanted as single plants and planted in hills, an experiment in the split factorial design in the format of randomized complete block design with three replications was conducted in Sari in 2007. The main factor consisted of two levels of silica (applying and not applying it), and the subordinate factor included two modes of planting rice (in hills and as individual plants) and three plant densities (40, 80, and 120 plants $/ \mathrm{m}^{2}$ ). Results obtained showed that applying silica improved some agronomic features. For example, the total number of tillers per plant increased by $11.6 \%$, the number of effective tillers per plant by $14.2 \%$, and the seed yield by $18.2 \%$; and, therefore, the harvest index, compared to the control (in which silica was not applied), increased by $4.4 \%$; but the percentage of filled spikelets decreased by $13.9 \%$ (which was a significant reduction). Increasing plant density from 40 to 120 plants per $\mathrm{m}^{2}$ caused deterioration in some agronomic features. For example, plant height, the total number of tillers, the number of effective tillers per plant, and the total number of spikelets per panicle decreased by $5.04,51.94,55.1$, and $20.44 \%$, respectively. The mode of planting had a significant effect only on the total number of effective tillers per plant, and on the total number of spikelets per panicle, at the one percent probability level; and it also significantly influenced the percentage of filled spikelets at the five percent probability level. Under the interactive effects of the three variables, the maximum seed yield was obtained in the treatment of applying silica and planting density of 80 plants per $\mathrm{m}^{2}$ in transplanting rice as single plants and in hill planting (424.1 and $414.6 \mathrm{~g} / \mathrm{m}^{-2}$, respectively).
\end{abstract}

Keywords: rice, silica, planting density, hills, seed yield

\section{Introduction}

Rice (Oryza sativa L.) is one of the most important cereals in the world; and it is exclusively consumed by man, though its stubble, husk, and hull have many applications. Rice is the main foodstuff of more than half the population of the earth. Rice is very adaptable to environmental conditions; and man has been successful in changing the lifestyle of this plant. Rice is grown all over the world, except in the poles, under different weather conditions; and it has great influence as an important foodstuff in the nutrition of mankind (Tanaka \& Park, 2006).

Silica is one of the most common substances found in the crust of the earth and in the ashes of plants (Johnson \& Hendricks, 1997); and, due to the positive effects of silicon in growing rice, it is considered a necessary element for this crop (Mengel \& Kirkby, 2007). Rice and wheat actively absorb silicon and its absorption is not influenced by the rate of transpiration. Silicon is mainly found in the aerial parts of rice: in the blade epidermis, the sclerenchyma, the vascular tissues, and the bundle sheaths of leaves; in the outer epidermis and along the cell walls of leaf and stem sheaths; Silicon is present in all the tissues of the roots, and is more abundant in old leaves than in young ones (Tanaka \& Park, 2006). In the rice plant, silicon causes an increase in the number of tillers, in the surface area of leaves, and in the photosynthetic activity of the lower leaves; and, in this way, it increases growth. Deficiency of silicon in rice causes the leaves to droop; and in sugarcane, its deficiency leads to leaf 
spots (Elawad et al., 2002). Silicon causes rice leaves to be erect and to live long; It increases dry matter, reduces transpiration, and causes an increase in the number of leaves, in the number of spikelets, and in seed weight. Silicon makes rice plants more resistant to fungal diseases, and raises the percentage of the filled spikelets and seed yield (Ma et al., 2009). In general, silicon increases the total number of spikelets per panicle, the percentage of filled spikelets, the 1000-seed weight; and it decreases lodging, and, in this way, raises rice seed yield (Kato \& Owa, 2000).

Determination of the suitable distance between plants can be an important feature of agronomical plans designed for obtaining high yields and desirable quality. Seed yield results from competition within and among plants to make use of the growth factors present in the environment; and maximum yield per unit area is realized when this competition is minimized and the plants can utilize the existing growth factors to the utmost (Koochaki \& Sarmadnia, 1997). Therefore, maximum utilization of factors of production for plant growth happens when the plant population absorbs as much of all the factors of production that it can; and, because of this, the plants in the plant community encounter great stress (Donald \& Daily, 1982). Therefore, when the level of soil fertility is high, the number of plants per unit area should be larger than when soil fertility is low (Tang \& King, 2000). If the economic yield only concerns seed yield, then the distance between plants should be set at a figure above which, because of the high plant density, the photosynthetates are used for vegetative growth or for plant respiration, instead of being used for seed development. Seed yield increases at high plant densities because there will be more panicles per unit area (Balooch et al., 2002). Hamid-Al-Islam and Eltaf Hossein (2002) reported that in the planting configuration of $25 \mathrm{~cm} \times 15 \mathrm{~cm}$, the total number of tillers and the number of effective tillers per hill were double the corresponding numbers in the planting configuration of $15 \mathrm{~cm} \mathrm{x} 10 \mathrm{~cm}$, but that the opposite situation existed for the number of seeds per panicle. Furthermore, with an increase in plant density, the number of unfilled spikelets per panicle went up (Fallah Amoli, 2005). Therefore, due to the importance of silicon and plant density, this research project was conducted to study the effects of using silica and planting density on the agronomic features of the Tarom Dilamani cultivar of rice planted in hills and as individual plants.

\section{Methods and Materials}

In order to study the effects of the application of silica and plant density on the morphological features, the yield, and the components of yield of the Tarom Dilamani cultivar of rice, an experiment was conducted in the north of the city of Sari (north of Iran), the latitude, longitude, and altitude of which are $36^{\circ} 33^{\prime}$ North, $53^{\circ}$ East, and 23 meters above sea level, respectively. The $\mathrm{pH}$ of the soil was 7.5 , and its organic carbon content was $1.2 \%$. The experiment was carried out using the split-factorial design in the randomized complete block format with three replications. The main factor was silica, with the two treatments of not applying it, and applying $250 \mathrm{Kg}$ of pure silica per hectare (in the form of mineral ash, which contained 60\% silica) after the transplanting operation. The subordinate factor consisted of two modes of planting (individual plants and three plants in each hill), and three levels of planting density $\left(40,80\right.$, and 120 plant $\left./ \mathrm{m}^{2}\right)$ in planting configurations of $16.6 \mathrm{~cm} \mathrm{x} 15 \mathrm{~cm}, 12.5 \mathrm{~cm} \mathrm{x} 10$ $\mathrm{cm}$, and $10 \mathrm{~cm} \times 8.3 \mathrm{~cm}$, respectively).

To conduct the experiment, first the nursery bed was prepared and the leveling and fertilizer application operations were carried out. Then, the seeds were disinfected using Vitavax Thiram; and after the seeds germinated in a suitable environment, they were broadcast in the nursery. The field where the experiment was conducted had been used for growing rice in previous years. It was plowed in late Feb using a reversible plow, and in the second half of April the complete land preparation operation (including spring plow, poling, and leveling) was performed. Then, the field was divided into three replications, each consisting of twelve 2 by 5 meter plots. At planting, $70 \mathrm{Kg}$ of urea per hectare, phosphorous in the form of concentrated superphosphate, potassium in the form of $100 \mathrm{Kg}$ of potassium sulphate per hectare, and silica (depending on the treatment) were applied to all of the plots. In this experiment, the Tarom Dilamani cultivar was planted according to plant density and mode of planting (individual plants or three plants in each hill). When the plants were $25 \mathrm{~cm}$ tall, they were transplanted to the main field (from the nursery); and two days later the plots were irrigated. At panicle initiation and after completion of panicle formation, 50 and $30 \mathrm{Kg}$ of urea per hectare, respectively, was applied to each plot as top dressing. Weeds were controlled twice by hand: once 20 days and the other time 40 days after transplanting. To control rice stem borer, the insecticide diazinon (in the form of $5 \%$ granules) was used three times. During the development of the rice crop, random samples were taken from each plot to measure the following features: Plant height and length of panicle were obtained by measuring them in 12 plants, The total number of tillers and the number of effective tillers were determined by measuring them in 12 plants, The number of panicles per unit area was calculated by counting the panicles on the plants present in one square meter, The total number of spikelets in each panicle and the percentage of filled spikelets were found by counting these features in 20 panicles from each plot, The 1000-seed weight was obtained by taking ten 100 -seed 
samples and weighing them when their moisture content was $12 \%$, The seed yield and the biological yield were determined by harvesting the plants existing in $4 \mathrm{~m}^{2}$ of the middle part of each plot. The seeds were weighed when their moisture content was $12 \%$. The seed yield was divided to the biological yield to calculate the harvest index. The analysis of the variance of the data gathered was performed by using the MSTAT-C statistical software; and the comparison of the means was carried out on the basis of Duncan's Multiple Range Test (DMTR) at the level of 5\% probability.

\section{Results and Discussion}

\subsection{Morphological Features}

The height of plants was statistically influenced by plant density at the level of probability of $5 \%$ (Table 1 ). The tallest plants $(150.8 \mathrm{~cm})$ were obtained at the density of $40 \mathrm{plant} / \mathrm{m}^{2}$, and plant height decreased by 5.04 percent when the density was increased to 120 plant $/ \mathrm{m}^{2}$. At the density of $80 \mathrm{plant} / \mathrm{m}^{2}$, plant height was $147.7 \mathrm{~cm}$. The length of panicle was not statistically influenced by any of the treatments; but it was $23.7 \mathrm{~cm}$ when silica was not applied and $23 \mathrm{~cm}$ when it was. The length of panicle, when rice was planted as individual plants, was $23.3 \mathrm{~cm}$, and it was $22.8 \mathrm{~cm}$ when rice was planted in hills. Length of panicle at densities of 40,80 , and $120 \mathrm{plant} / \mathrm{m}^{2}$ was 24.12, 22.48, and $22.57 \mathrm{~cm}$, respectively (Table 2). Agari et al. (1993) found that silicon caused an increase in vegetative growth and dry matter produced. Hosseini (2003) and Vojdani (2006) reported that a decrease in plant density resulted in an increase in plant height. Fallah Amoli (2005) remarked that an increase in the distance between plants led to an increase in the length of panicle, the reason for which was a reduction in competition among plants.

Table 1. Effects of Silica, cultivation pattern and plant density on rice agronomical traits

\begin{tabular}{|c|c|c|c|c|c|c|c|c|c|c|c|c|}
\hline \multicolumn{13}{|c|}{ Mean Square } \\
\hline $\begin{array}{l}\text { Source of } \\
\text { Variation }\end{array}$ & $\begin{array}{l}\text { Degree } \\
\text { of } \\
\text { Freedom }\end{array}$ & $\begin{array}{l}\text { Harvest } \\
\text { Index }\end{array}$ & $\begin{array}{l}\text { Biological } \\
\text { Yield }\end{array}$ & $\begin{array}{l}\text { Seed } \\
\text { Yield }\end{array}$ & $\begin{array}{l}1000- \\
\text { seed } \\
\text { weight }\end{array}$ & $\begin{array}{l}\text { Filled } \\
\text { spikelet }\end{array}$ & $\begin{array}{l}\text { Spikelet } \\
\text { per } \\
\text { panicle }\end{array}$ & $\begin{array}{l}\text { No. of } \\
\text { panicle. } \\
\mathrm{m} 2\end{array}$ & $\begin{array}{l}\text { No. of } \\
\text { effective } \\
\text { tiller. } \\
\text { m2 }\end{array}$ & $\begin{array}{l}\text { No. of } \\
\text { tiller. } \\
\text { plant }\end{array}$ & $\begin{array}{l}\text { Spike } \\
\text { length }\end{array}$ & $\begin{array}{l}\text { Plant } \\
\text { Height }\end{array}$ \\
\hline \multirow[t]{2}{*}{ Replication } & 2 & 1.367 & 28977.6 & 913.38 & 2.434 & 75.672 & 255.04 & 2554.33 & $3.529 \mathrm{~ns}$ & 3.084 & 1.51 & 285.25 \\
\hline & & & $\mathrm{ns}$ & ns & ns & $\mathrm{ns}$ & $\mathrm{ns}$ & $\mathrm{ns}$ & & $\mathrm{ns}$ & & $\mathrm{ns}$ \\
\hline \multirow[t]{2}{*}{ Silica (A) } & 1 & $168.56^{*}$ & 36125.33 & 42120.71 & 0.422 & 1042.21 & 353.44 & 821.77 & $4.914 *$ & 3.480 & 0.001 & 83.11 \\
\hline & & & ns & $*$ & $\mathrm{~ns}$ & $*$ & $\mathrm{~ns}$ & ns & & $*$ & ns & ns \\
\hline Cultivation & 1 & 13.32 & $595.36 \mathrm{~ns}$ & 139.24 & 0.422 & 412.76 & 1133.44 & 29258.77 & 31.547 & 31.174 & 2.668 & 77.73 \\
\hline Pattern (B) & & & & $\mathrm{ns}$ & $\mathrm{ns}$ & $*$ & $* *$ & $*$ & $* *$ & $* *$ & ns & $\mathrm{ns}$ \\
\hline \multirow[t]{2}{*}{$\mathrm{AxB}$} & 1 & $0.047 \mathrm{~ns}$ & $936.36 \mathrm{~ns}$ & 390.72 & 12.08 & 33.44 & 40.960 & 469.44 & $0.563 \mathrm{~ns}$ & 3.547 & 0.751 & 88.04 \\
\hline & & & & $\mathrm{ns}$ & $\mathrm{ns}$ & $\mathrm{ns}$ & ns & $\mathrm{ns}$ & & ns & ns & $\mathrm{ns}$ \\
\hline Density & 2 & 15.72 & 2887.86 & 5114.92 & 3.99 & 382.95 & 1148.62 & 7322.58 & 59.537 & 65.34 & 10.154 & 175.78 \\
\hline (C) & & ns & ns & ns & $\mathrm{ns}$ & $*$ & $* *$ & $\mathrm{~ns}$ & $* *$ & $* *$ & ns & $*$ \\
\hline \multirow[t]{2}{*}{$\mathrm{AxC}$} & 2 & $6.53 \mathrm{~ns}$ & 40197.15 & 5478.03 & $7.3 \mathrm{~ns}$ & 67.08 & 73.231 & 3196.52 & $1.730 \mathrm{~ns}$ & 0.753 & 8.361 & 59.15 \\
\hline & & & ns & ns & & $\mathrm{ns}$ & $\mathrm{ns}$ & ns & & $\mathrm{ns}$ & ns & ns \\
\hline \multirow[t]{2}{*}{$\mathrm{BxC}$} & 2 & $90.79 * *$ & 43476.68 & 2360.49 & 1.39 & 117.4 & 74.35 & 6930.528 & 5.225 & 7.512 & 0.348 & 0.36 \\
\hline & & & ns & ns & $\mathrm{ns}$ & $\mathrm{ns}$ & $\mathrm{ns}$ & ns & $* *$ & $*$ & ns & $\mathrm{ns}$ \\
\hline \multirow[t]{2}{*}{$\mathrm{ABC}$} & 2 & 74.49 & 10607.04 & 1512.29 & 2.512 & 198.58 & 38.42 & 435.361 & $0,198 \mathrm{~ns}$ & 0.105 & 5.631 & 13.66 \\
\hline & & $* *$ & & $\mathrm{~ns}$ & $\mathrm{~ns}$ & $\mathrm{~ns}$ & $\mathrm{~ns}$ & $\mathrm{~ns}$ & & $\mathrm{~ns}$ & $\mathrm{~ns}$ & $\mathrm{~ns}$ \\
\hline CV (\%) & & 9.11 & 12.74 & 14.74 & 7.56 & 12.31 & 12.51 & 16.36 & 23.88 & 25.73 & 7.78 & 5.04 \\
\hline
\end{tabular}


Table 2. Comparison of the means of the data related to effects of Silica, cultivation pattern and plant density on rice agronomical traits

\begin{tabular}{|c|c|c|c|c|c|c|c|c|c|c|c|}
\hline Treatment & $\begin{array}{l}\text { Harvest } \\
\text { Index }\end{array}$ & $\begin{array}{l}\text { Biological } \\
\text { Yield } \\
\text { (g.m2) }\end{array}$ & $\begin{array}{l}\text { Seed } \\
\text { Yield } \\
\text { (g.m2) }\end{array}$ & $\begin{array}{l}1000- \\
\text { seed } \\
\text { weight } \\
\text { (g) }\end{array}$ & $\begin{array}{l}\text { Filled } \\
\text { spikelet } \\
(\%)\end{array}$ & $\begin{array}{l}\text { Spikelet } \\
\text { per } \\
\text { panicle }\end{array}$ & $\begin{array}{l}\text { No. of } \\
\text { panicle. } \\
\mathrm{m} 2\end{array}$ & $\begin{array}{l}\text { No. of } \\
\text { effective } \\
\text { tiller. m2 }\end{array}$ & $\begin{array}{l}\text { No. of } \\
\text { tiller. } \\
\text { plant }\end{array}$ & $\begin{array}{l}\text { Spike } \\
\text { length } \\
(\mathrm{cm})\end{array}$ & $\begin{array}{l}\text { Plant } \\
\text { Height } \\
(\mathrm{cm})\end{array}$ \\
\hline \multicolumn{12}{|l|}{ Silica } \\
\hline Control & $34.5 \mathrm{~b}$ & $909.8 \mathrm{a}$ & $308.2 \mathrm{~b}$ & $21.7 \mathrm{a}$ & $77.2 \mathrm{a}$ & $82 \mathrm{a}$ & $345.4 \mathrm{a}$ & $4.8 \mathrm{a}$ & $5.4 \mathrm{~b}$ & $23.7 \mathrm{a}$ & $145.7 \mathrm{a}$ \\
\hline Treatment & $38.9 \mathrm{a}$ & $973 \mathrm{a}$ & $376.6 \mathrm{a}$ & $21.7 \mathrm{a}$ & $66.4 \mathrm{~b}$ & $88.2 \mathrm{a}$ & $335.9 \mathrm{a}$ & $5.6 \mathrm{a}$ & $6.1 \mathrm{a}$ & $23 \mathrm{a}$ & $148.7 \mathrm{a}$ \\
\hline \multicolumn{12}{|l|}{ Cultivation } \\
\hline Individual plants & $37.3 \mathrm{a}$ & $937.4 \mathrm{a}$ & $344.3 \mathrm{a}$ & $21.9 \mathrm{a}$ & $68.4 \mathrm{~b}$ & $90.7 \mathrm{a}$ & $316.9 \mathrm{~b}$ & $6.1 \mathrm{a}$ & $6.7 \mathrm{a}$ & $23.3 \mathrm{a}$ & $148.7 \mathrm{a}$ \\
\hline Hill planting & $36.1 \mathrm{a}$ & $954.6 \mathrm{a}$ & $340.4 \mathrm{a}$ & $21.7 \mathrm{a}$ & $75.2 \mathrm{a}$ & $79.5 \mathrm{~b}$ & $364.4 \mathrm{a}$ & $4.3 \mathrm{~b}$ & $4.8 \mathrm{~b}$ & $22.8 \mathrm{a}$ & $145.7 \mathrm{a}$ \\
\hline \multicolumn{12}{|l|}{ Plant density } \\
\hline 40 Plant.m2 & $35.9 \mathrm{a}$ & $938.8 \mathrm{a}$ & $336.3 \mathrm{a}$ & $21.52 \mathrm{a}$ & $65.54 \mathrm{a}$ & $95.34 \mathrm{a}$ & $363.6 \mathrm{a}$ & $7.7 \mathrm{a}$ & $8.39 \mathrm{a}$ & $24.12 \mathrm{a}$ & $150.8 \mathrm{a}$ \\
\hline 80 Plant.m2 & $38 \mathrm{a}$ & $958.2 \mathrm{a}$ & $365.4 \mathrm{a}$ & $22.47 \mathrm{a}$ & $76.54 \mathrm{a}$ & $84.11 \mathrm{ab}$ & $343.9 \mathrm{a}$ & $4.4 \mathrm{~b}$ & $4.76 \mathrm{~b}$ & $22.48 \mathrm{a}$ & $147.7 \mathrm{a}$ \\
\hline 120 Plant.m2 & $36.1 \mathrm{a}$ & $927.5 \mathrm{a}$ & $325.5 \mathrm{a}$ & $21.42 \mathrm{a}$ & $73.28 \mathrm{a}$ & $75.84 \mathrm{~b}$ & $314.5 \mathrm{a}$ & $3.45 \mathrm{~b}$ & $4.03 \mathrm{~b}$ & $22.57 \mathrm{a}$ & $143.2 \mathrm{a}$ \\
\hline
\end{tabular}

Numbers having common letters in each column are not significantly different at the probability level of 5 percent.

\subsection{Seed Yield and Its Components}

The number of panicles per plant showed a statistically significant difference at the level of probability of one percent with regard to the influence of planting density and the mode of planting rice, and also a statistically significant difference at the level of five percent probability as far as the mutual effects of mode of planting and plant density were concerned (Table 1). The number of tillers per hill was $11.62 \%$ larger when $250 \mathrm{Kg}$ of silica per hectare was applied than the corresponding number (5.4) when silica was not used. The number of tillers per plant (in transplanting individual plants) and the number of tillers per hill were 6.7 and 4.8 , respectively. The maximum number of tillers per hill (8.39) was observed in the density of $40 \mathrm{plant} / \mathrm{m}^{2}$, and it decreased by $51.96 \%$ when the density increased to $120 \mathrm{plant} / \mathrm{m}^{2}$ (Table 2 ). The maximum number of tillers per plant (in the interaction effects of planting mode and plant density) was achieved in hill planting at the density of $40 \mathrm{plant} / \mathrm{m}^{2}$ (10.2), and the minimum (3.5) at the density of $120 \mathrm{plant} / \mathrm{m}^{2}$ (Figure 1). Silicon enhances growth in rice through increasing the number of tillers per plant (Kato \& Owa, 1990; Agari et al., 1993). Mohseni Delarestaghi (2007) noticed that the total number of tillers per plant decreased when plant density increased to $120 \mathrm{plant} / \mathrm{m}^{2}$. Vojdani (2006) also obtained similar results. Hamid-Al-Islam and Eltaf Hossein (2002) reported that the number of tillers per hill increased when plant density was lowered, because seedlings had more access to light and plant nutrients.

\subsection{The Number of Effective Tillers per Plant}

The number of effective tillers per plant showed a statistically significant difference at the level of five percent probability under the interaction effects of mode of planting and silica application (Table 1). The number of effective tillers per plant, when rice was transplanted as single plants, was larger than the number in hill planting (6.1 and 4.3, respectively). The maximum number of effective tillers per plant under the influence of different plant densities (7.7) was observed at the density of $40 \mathrm{plant} / \mathrm{m}^{2}$, and it decreased by $55.1 \%$ when plant density was raised to $120 \mathrm{plant} / \mathrm{m}^{2}$. It can also be seen that the number of effective tillers per hill increased by $14.2 \%$ when silica was applied; in other words, the number of effective tillers per plant, in the treatments of not applying silica and applying it, were 4.8 and 5.6, respectively (Table 2). The maximum number of effective tillers per plant, under the mutual influences of the mode of planting and plant density in transplanting rice as single plants, was obtained at the density of $40 \mathrm{plant} / \mathrm{m}^{2}$ (9.36), and the minimum number (2.7) was observed in hill planting at the density of $120 \mathrm{plant} / \mathrm{m}^{2}$ (Figure 2). With an increase in the number of plants of various rice genotypes per unit area of land, the vegetative buds will be less stimulated to grow, and hence the number of tillers and effective tillers per plant will decrease, because there will be intense competition among plants, and due to the fact that light cannot reach the floor of plant communities (Mobasser et al., 2007). Mohseni 
Delarestaghi (2007) noticed that the maximum and minimum number of effective tillers per plant was obtained at densities of 40 and 120 plant $/ \mathrm{m}^{2}$, respectively. Pall et al. (2002) also reported similar results.

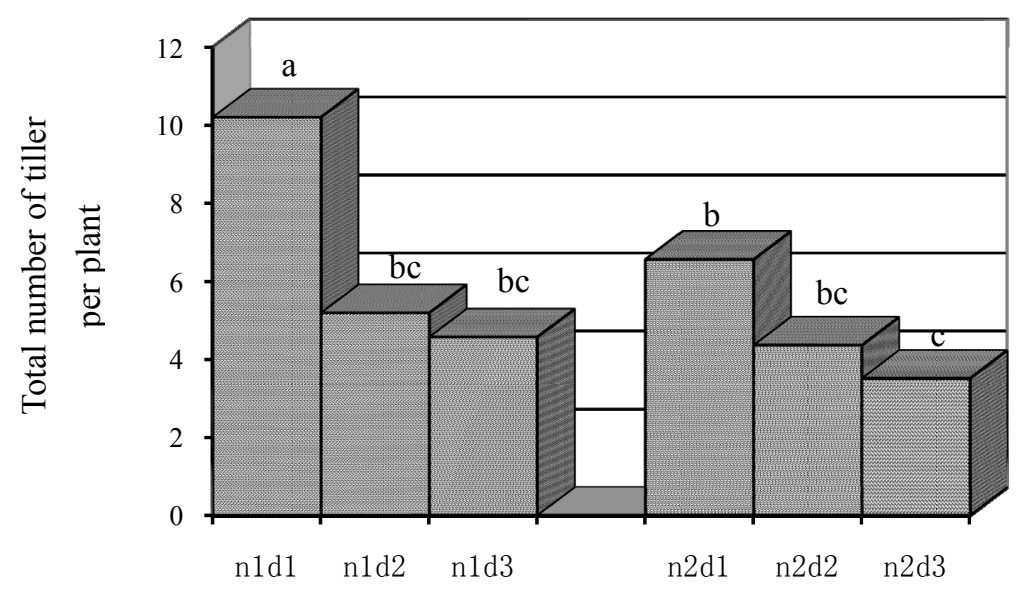

Figure 1. Interaction effects of cultivation pattern $\mathrm{x}$ plant density on total number of tiller per plant. $\mathrm{n} 1=$ Individual plants, $\mathrm{n} 2=$ Hill planting, $\mathrm{d} 1=40$ Plant. $\mathrm{m}^{2}$, $\mathrm{d} 2=80$ Plant. $\mathrm{m}^{2} \mathrm{~d} 3=120$ Plant. $\mathrm{m}^{2}$

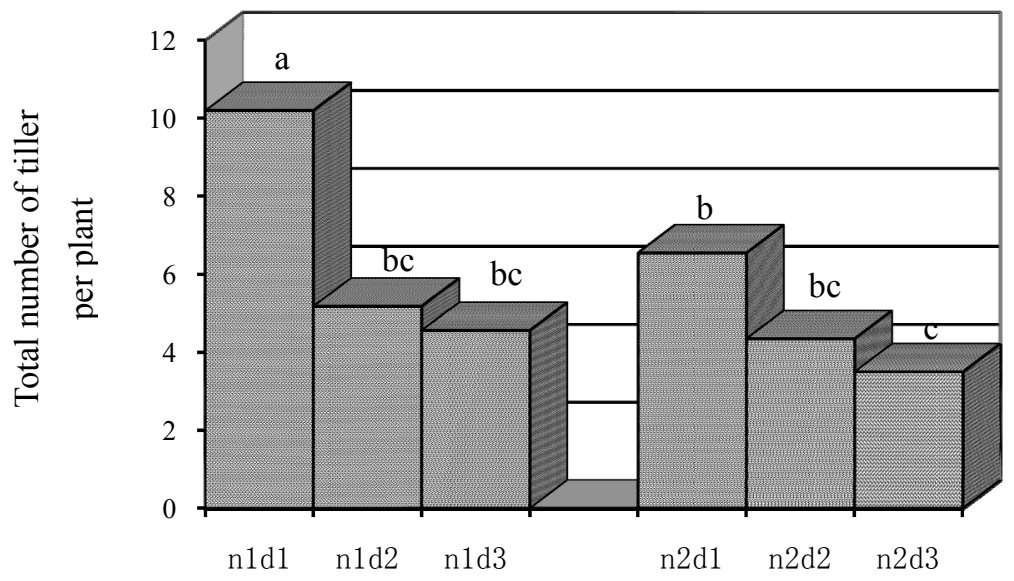

Figure 2. Interaction effects of cultivation pattern $\mathrm{x}$ plant density on number of erective tiller per plant. $\mathrm{n} 1=$ Individual plants, $\mathrm{n} 2=$ Hill planting, $\mathrm{d} 1=40$ Plant. $\mathrm{m}^{2}, \mathrm{~d} 2=80$ Plant. $\mathrm{m}^{2}, \mathrm{~d} 3=120$ Plant. $\mathrm{m}^{2}$

\subsection{The Number of Panicles per Square Meter}

The number of panicles $/ \mathrm{m}^{2}$ is statistically influenced at the $5 \%$ probability level only by the mode of planting, so that in hill planting (with three plants per hill) it was $13.03 \%$ larger than the number in transplanting rice as single plants (where the number was 316.9). The maximum number of panicles per unit area at different plant densities (363.6) was achieved at the density of $40 \mathrm{plant} / \mathrm{m}^{2}$, and the minimum (314.5) at 120 plant $/ \mathrm{m}^{2}$; furthermore, these numbers were 345.4 and 335.9 in the treatments of not applying and applying silica, respectively (Table 1). Other researchers noticed that with an increase in plant density in rice, the number of panicles $/ \mathrm{m}^{2}$ increased, because there were more stems per unit area (Mobasser et al., 2007; Vojdani, 2006; Mohseni Delarestaghi, 2007).

\subsection{The Number of Spikelets per Panicle}

Results of the analysis of the variance indicates that the total number of spikelets per panicle was statistically under the influence of the mode of planting and plant density, and that it showed a significant difference at the one percent probability level, so that it was $12.3 \%$ greater in transplanting single plants compared with hill planting (where the number was 79.5); furthermore, the maximum number of spikelets per panicle (95.34) was 
achieved at $40 \mathrm{plant} / \mathrm{m}^{2}$, and it dropped by 20.44 percent when the density went up to $120 \mathrm{plant} / \mathrm{m}^{2}$ (Table 2).

Mohseni Delarestaghi (2007) noticed that by raising plant densities of various rice genotypes to $120 \mathrm{plant} / \mathrm{m}^{2}$, the total number of spikelets per panicle went down by 22.47\%. Vojdani (2006) and Mobasser et al (2007), obtained similar results, but Hamid-Al-Islam and Eltaf Hossein (2002) reported that plant density did not have a significant effect on the total number of spikelets per panicle. Contrary to the results of this study, Agari et al (1993) reported that applying silica raised the total number of spikelets per panicle, because it increased the levels of carbohydrates and dry matter produced.

\subsection{The Percentage of Filled Spikelets}

The percentage of filled spikelets was statistically influenced by silica application, mode of planting, and plant density at the level of 5\% probability. The percentage of filled spikelets went down by $13.9 \%$ when silica was applied (from the $77.2 \%$ when silica was not applied). The percentage of filled spikelets in hill planting with three plants per hill (75.2\%) was 9.04\% higher than when rice was transplanted as single plants (Table 2). The maximum percentage of filled spikelets at different plant densities (76.54) was achieved at $80 \mathrm{plant} / \mathrm{m}^{2}$, while this percentage was 65.54 and $73.28 \%$ at densities of 40 and $120 \mathrm{plant} / \mathrm{m}^{2}$, respectively (Table 2). Mobasser et al. (2007) and Vojdani (2006) noticed that the percentage of filled spikelets was not influenced by plant density, but Balooch et al. (2002) showed that the maximum percentage of filled spikelets was achieved at lower densities. If silica was not applied, the percentage of filled spikelets decreased by $40 \%$ (Mao et al., 2009). Other researchers have also stated that silicon raises the percentage of filled spikelets (Agari et al., 1993).

\subsection{The 1000-seed Weight}

The 1000-seed weight was not statistically influenced by any of the treatments, but seed yield was only influenced by silica application at the $5 \%$ probability level (Table 1 ).

\subsection{Seed Yield}

Applying silica raised seed yield by $18.2 \%$, compared to the treatment of not applying it (which had a seed yield of $308.2 \mathrm{~g} / \mathrm{m}^{2}$ ). Seed yield in transplanting single plants and hill planting was 344.3 and $340.4 \mathrm{~g} / \mathrm{m}^{2}$, respectively; and it was also $336.3,365.4,325.5 \mathrm{~g} / \mathrm{m}^{2}$ at densities of 40,80 , and $120 \mathrm{plant} / \mathrm{m}^{2}$, respectively (Table 2). The maximum seed yield under the interaction effects of silica application, mode of planting, and plant density in the treatments of applying silica in hill planting (three plants per hill) at the density of $80 \mathrm{plant} / \mathrm{m}^{2}$, and applying silica in transplanting single plants at the density of $80 \mathrm{plant} / \mathrm{m}^{2}$, was 424.1 and $414.1 \mathrm{~g} / \mathrm{m}^{2}$, respectively, while the minimum seed yield in the treatments of not applying silica in transplanting rice as single plants at the density of 40 plant $/ \mathrm{m}^{2}$, and not applying silica in hill planting at the density of 120 plant $/ \mathrm{m}^{2}$, was 288.7 and $288.6 \mathrm{~g} / \mathrm{m}^{2}$, respectively (Figure 3 ).

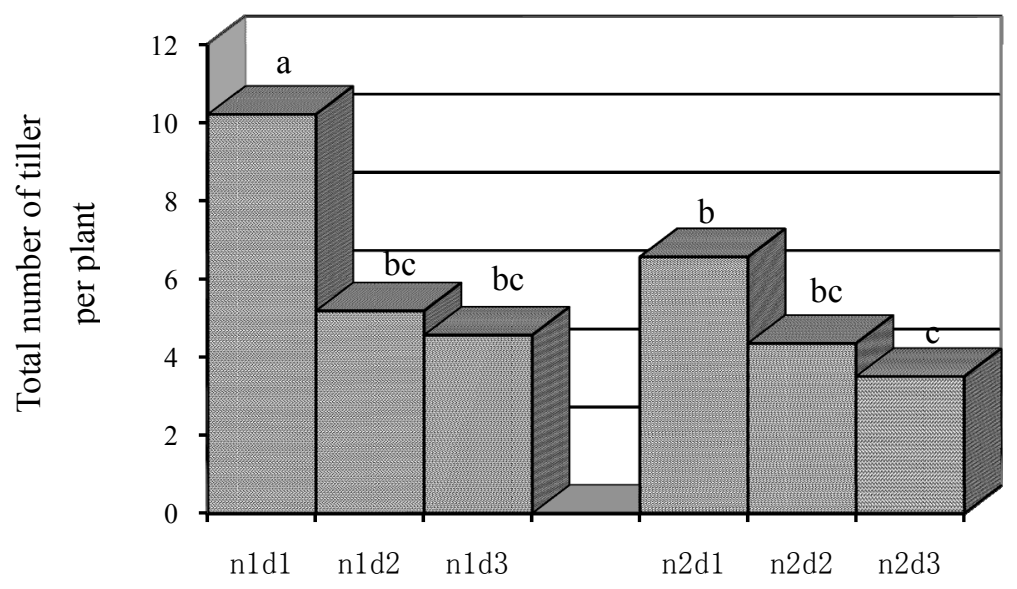

Figure 3. Interaction effects of cultivation pattern $\mathrm{x}$ plant density on number of seed yield. $\mathrm{n} 1=$ Individual plants, $\mathrm{n} 2=$ Hill planting, $\mathrm{d} 1=40$ Plant. $\mathrm{m}^{2}, \mathrm{~d} 2=80$ Plant. $\mathrm{m}^{2}$, $\mathrm{d} 3=120$ Plant. $\mathrm{m}^{2}$ 
Mao et al. (2009) found that applying silica raised seed yield through increasing the total number of spikelets per panicle, the percentage of filled spikelets, and the 1000- seed weight. They also reported that lack of silicon decreased the percentage of filled spikelets by $40 \%$, lowered the total number of spikelets per panicle by $10 \%$, and raised seed yield by $8 \%$. Mobasser et al (2007) stated that increasing plant density in rice raises seed yield, although the total number of tillers per hill goes down due to the increased number of stems per unit area; and their results are similar to those obtained by Balooch et al. (2002) and Vojdani (2006).

\subsection{The Biological Yield}

The results showed that, the biological yield was not statistically influenced in any of the treatments (Table 1). The biological yield did not significantly differ when silica was applied, because it was 973 and $909.8 \mathrm{~g} / \mathrm{m}^{2}$ when silica was not applied, and when it was, respectively. The biological yield was also more in hill planting (with three plants per hill) than in transplanting rice as single plants, with 954.6 and $937.4 \mathrm{~g} / \mathrm{m}^{2}$, respectively (Table 2). The biological yield did not significantly increase at different plant densities (Table 1), as it was 958.2, 938.8, and $927.5 \mathrm{~g} / \mathrm{m}^{2}$ at 80,40 , and $120 \mathrm{plant} / \mathrm{m}^{2}$, respectively (Table 2). Mobasser et al. (2007) stated that biological yield was statistically influenced by plant density, so that the highest biological yields for various rice genotypes were achieved at densities of 100 and $120 \mathrm{plant} / \mathrm{m}^{2}$.

\subsection{The Harvest Index}

The harvest index was influenced by silica application at the probability level of $5 \%$, by the interaction effects of the mode of planting and plant densities at the one percent probability level, and by silica application, the mode of planting, and plant density (also at one percent probability level) (Table 1). The harvest index with silica application (38.9\%) was $4.4 \%$ higher than when silica was not applied. The harvest index in hill planting and transplanting single plants was 37.3 and $36.1 \%$ respectively; and it was $35.9,38$, and $36.1 \%$ at densities of 40,80 , and $120 \mathrm{plant} / \mathrm{m}^{2}$, respectively.

The maximum harvest index under the triple mutual effects (44\%) was achieved in the treatment of applying silica, transplanting single plants, and the density of $80 \mathrm{plant} / \mathrm{m}^{2}$, and the minimum (29.1\%) was obtained in the treatment of not applying silica, hill planting, and the density of $120 \mathrm{plant} / \mathrm{m}^{2}$ (Figure 4). Mobasser et al. (2007) found that the maximum harvest index was observed at 60 and the minimum at $100 \mathrm{plant} / \mathrm{m}^{2}$. Vojdani (2006) reported that with an increase in plant density, the stubble yield increased more than the seed yield, and hence the harvest index decreased. Agari et al. (1993) stated that silicon raises the total number of spikelets per panicle and increases the 1000-seed weight; and thereby the harvest index goes up. Other scholars also reported similar results (Datnoff et al., 1997).

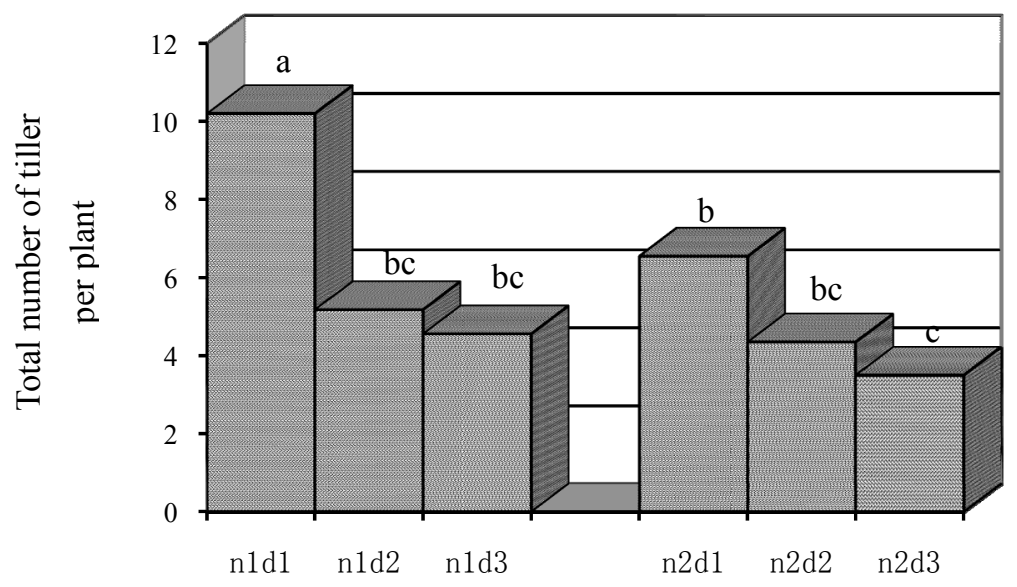

Figure 4. Interaction effects of cultivation pattern $\mathrm{x}$ plant density on number of Harvest Index. $\mathrm{n} 1=$ Individual plants, $\mathrm{n} 2=$ Hill planting, $\mathrm{d} 1=40$ Plant $. \mathrm{m}^{2}, \mathrm{~d} 2=80$ Plant. $\mathrm{m}^{2} \mathrm{~d} 3=120$ Plant. $\mathrm{m}^{2}$

\section{References}

Agari, S., Uchida, H., Agata, W., Kubota. F., \& Kaufman, B. (1993). Effect of silicon on growth. Dry matter production and photosynthesis in rice. Crop Production and Improvement Technology, 34.

Balooch, A. W., Soomro, A. M., Jarved, M. A., \& Ahmed, M. (2002). Optimum plant density for high yield in 
rice (Oryza sativa L.). Asian Journal of Plant Science, $1(1), \quad 25-27$. http://dx.doi.org/10.3923/ajps.2002.25.27

Datnoff, L., Dren, C. W., \& Snyder, G. H. (1997). Silicon fertilization for disease management of rice Florida. Crop Production, 16(6), 525-531. http://dx.doi.org/10.1016/S0261-2194(97)00033-1

Donald, R., \& Daily, R. (1982). Rice growth analysis. $74^{\text {th }}$ Annual progress report rice experiment stotion Crowley. Louisana, 159-172.

Elawad, S. H., Gascho, G. J., \& Street, J. J. (2002). Response of sugarcane of silicate source and rate. I. Growth and yield. Agronomy Journal, 74, 781-783.

Fallah Amoli, H. (2005). Study of the effect of date of planting, plant density, and different levels of nitrogen fertilizer application on the morphology and harvest index of the promising new line of Rice 825, M. SC. thesis, Islamic Azad University of Tehran, Department of Sciences and Research, pp 117.

Hamid, A. I., \& Eltaf, H. (2002). Effect of fertilization and plating density on the yield of two varieties of fine rice. Pakistan Journal of Biological Science, 4(5), 513-516.

Hosseini, S. S. (2003). Study of the effects of transplanting, distance between plants, and application of nitrogen fertilizers on the harvest index, yield and yield components of rice (Line 108). M.Sc. Thesis in Agronomy, University of Mazandaran. pp 910.

Johnson, L. H., \& Hendricks, K. A. (1997). Silica in soils and plants. Agronomy Journal, 19, 107-109.

Kato, N., \& Owa, N. (2000). Dissolution mechanism of silicate slage fertilizes in paddy. Soil Science and Plant Nutrition, 4, 609-610.

Koochaki, A., \& Gh, Sarmadnia. (1997). Crop Plant Physiology. Mashhad University Jihad Publications, pp 468.

Mao, J., Nishimara, K., \& Takashi, E. (2009). Effect of silicon on the growth of rice at different growth stages. Soil Science and Plant Nutrition, 32, 347-356.

Mengel, K., \& Kirkby, E. A. (2007). Principles of plant nutrition $4^{\text {th }}$ Edition international potash Ins. Bern, Switzerland. pp. 687.

Mobasser, H. R., Barai Tari, D., Vojdani M., Sadrabadi, R., \& Eftekhari, A. (2007). Effect of seedling age and planting space on yield and yield components or rice (Neda variety). Asian Journal of Plant Science, 6(2), 438-440. http://dx.doi.org/10.3923/ajps.2007.438.440

Mohseni Delarestaghi, M. (2007). Study of the effects of different plant densities on the agronomic features of various rice genotypes. M.Sc. Thesis, Khorramabad Islamic Azad University. pp 84.

Pall, R. K., Taleb, M. A., \& Hossain, M. B. (2002). Effect of planting method and hill arrangement on the yield components of late transplanted a man rice frown under different planting dates. Pakistan Journal of Biological Sciences, 5(11), 1232-1236. http://dx.doi.org/10.3923/pjbs.2002.1232.1236

Tanaka. A., \& Park, Y. D. (2006). Significance of the absorption and distribution of silica in the growth of the rice plants. Soil Science and Plant Nutrition, 12, 25-28.

Tang, W., \& King, F. (2000). Effect of sowing density and fertilizer application on hybrid early rice cultivar. Zhegiang Nongue Kezue, 6, 269-273.

Vojdani, M. (2006). Study of the effects of the age of seedlings transplanted and of the planting configuration on the agronomic features of the rice cultivar Neda. M.Sc. thesis, Mashhads Islamic Azad University. pp 95. 